\title{
Prevalence of HCV Antibodies and HBV Surface Antigen among Workers of Zagazig Faculty of Medicine and its Hospitals
}

\author{
Sahar G.Zaghloul ${ }^{1}$, Magda M.Sherif ${ }^{1}$, Hoda Abd El-Aziz El-Hady ${ }^{1}$, \\ Sahar A. El-Nemr ${ }^{2}$ \\ ${ }^{1}$ Internal Medicine Department, Faculty of Medicine, Zagazig University, Egypt \\ ${ }^{2}$ Tropical Medicine Department, Faculty of Medicine, Zagazig University, Egypt
}

Corresponding Author Magda Mahrous Sherif

Mobile:

$+2(01156421353)$

$+2(055) 2308298$

E mail:

Magyakm2000@yahoo .com.

Key words: Hepatitis C virus antibodies $(\mathrm{HCV}$ Abs), Hepatitis B surface antigen (HBsAg), Intensive care unit (ICU)
Background and study aim: Viral hepatitis is a serious global public health problem affecting billions of people globally, and both hepatitis B virus (HBV) and hepatitis $\mathrm{C}$ virus (HCV) infections are rapidly spreading in the developing countries including Egypt due to the lack of health education, poverty, and and illiteracy. So this study was conducted to determine the prevalence of $\mathrm{HCV}$ antibodies and HBsAg and possible risk factors of transmission of these infections among workers of Zagazig Faculty of medicine and its hospitals.

Patients and Methods: This study was conducted on two hundred workers (non medicals) All were randomly selected from all clinical and academic Departments of Zagazig Faculty of Medicine and its Hospitals. Their age was above 18 years and up to 60 years. Possible associated factors with infections by the viruses were collected from patient using questionnaire Rapid diagnostic test kits were used to screen for Hepatitis B surface antigen (HBsAg) and antiHepatitis $\mathrm{C}$ virus (HCV) antibodies.

Results: Out of two hundred 39 (19.5\%)of workers had Hepatitis C virus (HCV) antibodies and $7(3.5 \%)$ of workers had Hepatitis B surface antigen and one worker $1((0.5 \%)$. had dual hepatitis $\mathrm{B}$ and $\mathrm{C}$ virus coinfection. The prevalence of chronic $\mathrm{HCV}$ and $\mathrm{HBV}$ is higher among males $(20.2 \%$ and $4 \%$ respectively) than females $(17.3 \%$ and $1.92 \%$ ) and both HBsAg and HCV Abs was ( 0.7$) \%$ in males and negative in females. The prevelance of HCV Abs was high among workers with past history of barbering $(69.23 \%)$ while prevalence of

\section{INTRODUCTION}

Chronic hepatitis $\mathrm{C}$ virus (HCV) infection remains a global health threat with 175 million carriers worldwide. Approximately 3\% of the
HBV was high in workers with a history of blood transfusion (28.57\%).Multivariate regression was used to estimate independent effects of risk factors on seropositivity of both virsus . A highly significant association was found between workers with history barbering (OR 4.58 ) and those with seroposiotivity of $\mathrm{HCV}$ abs. While there was no significant association between workers with a history of dental procedure(OR 1.44), operation (OR 1.2) and blood transfusion(OR 1.5) and those with acquired seropositivity of HCVAbs. And a highly significant association was found between workers with history of blood transfusion and those with acquired seropositivity of HBV ( OR 8.18), while there was no significant association between workers with a history of dental procedure(OR 0.2), barbering(OR 0.59) and operation (OR 0.63) and those with acquired seropositivity of $\mathrm{HBs}$.

Conclusion: We can conclude that he prevalence of $\mathrm{HBV}$ and $\mathrm{HCV}$ infections among workers of Zagazig Faculty of Medicine and its hospitals in this study is high .Barbering has 4 times risk of $\mathrm{HCV}$ infection and blood transfusion has 8 times $\mathrm{HBV}$ infection. and working in operation units was associated with increase the risk of $\mathrm{HBV}$ and $\mathrm{HCV}$ infections, but working in other units like surgical and non surgical, administration and ICU was associated with increase $\mathrm{HCV}$ transmission. For prevention the spread of HBV and HCV, people must be educated about these infections and modes of transmission, better infection control practices in hospitals, healthcare and barbering facilities.

worldwide population is infected with the hepatitis $\mathrm{C}$ virus (HCV) [1]. The prevalence of $\mathrm{HCV}$ infection varies throughout the world Egypt has the highest prevalence of hepatitis $C$ virus (HCV) in the world[2]. 
Estimated nationally at $14.7 \%$. This nation has weathered the largest iatrogenic transmission epidemic of blood-borne pathogens in human history during the era of parenteral antischistosomal therapy and circumcision among males administered by health-care workers using improperly sterilized glass syringes [3]. $\mathrm{HCV}$ transmission is ongoing in Egypt, and incidence rates have been estimated at 2.4 per 1,000 person-years $(165,000$ new infections annually) [4]. overall, an estimated 6 million Egyptians had chronic HCV infection in 2008. Primary modes of HCV transmission include unsafe injections, other inadequate infection control practices, and unsafe blood transfusions[6,7]. HCV transmission also occurs among injection-drug users in Egypt [8].

Hepatitis B infections are major health problems in Egypt and the entire continent of Africa. Egypt is considered to be a region of intermediate prevalence for $\mathrm{HBV}$ infection with a reported $3 \%-11 \%$ [8] The Hepatitis B Virus (HBV) is transmitted hematogenously and sexually. The outcome of this infection is a complicated viral host interaction that results in either an acute symptomatic disease or an asymptomatic disease.

Patients may become immune to the Hepatitis B Virus (HBV), or they may develop a chronic carrier state. Later consequences are cirrhosis and the development of hepatocellular carcinoma [9] It is approximately $90 \%$ for an infection acquired perinatally, and is as low as 5\% (or even lower) for adults [10].

The incidence of new infections has decreased in most developed countries, most likely due to the implementation of vaccination strategies [11]. Therefore, transmission from healthcare workers to patients is rare event, while the risk of transmission from an HBV-positive patient to a healthcare worker seems to be higher. Healthcare workers positive for hepatitis B are not generally prohibited from working. However, the individual situation has to be evaluated in order to decide on the necessary measures. The highest risk factor in most instances is injection drug use [9]. Although direct percutaneous inoculation is the most direct mode of transmission of HCV and HBV, several studies have demonstrated that sexual, household, occupational and vertical transmission may also be of importance[12]. Blood is one of the major sources of transmission of $\mathrm{HBV}, \mathrm{HCV}$, and physicians and patients are becoming more concerned about safe transfusion of blood [13]. The aim of the present study was to measure the prevalence of anti-HCV and HBsAg and possible risk factors of transmission of these infections among workers of Zagazig Faculty of medicine and its hospitals.

\section{MATERIALS AND METHODS}

The people recruited to the study were informed about the objectives of the study and that they were free to refuse participation. A verbal witnessed consent was obtained from each study participant. The study included a total number of two hundred workers. All workers (non medicals) were randomly selected from all clinical and academic Departments of Zagazig Faculty of Medicine and its Hospitals including surgical departments (general, cardiothoracic, gynecological and obstetric and surgical emergencies) and non surgical departments (Internal medicine, Pediatric and academic departments). The age of all workers was above 18 years and up to 60 years. All workers were selected to be non diabetic patients, non smokers, free from hepatic disorders, lung disease, renal disorders, acute inflammatory conditions, or acute infections and not receiving any drugs that are known to affect the liver.

All the subjects included in the study were subjected for full history taking, physical examination and Possible associated factors with infections by the viruses were collected from patient using questionnaire The questionnaire included socio-demographic data ,type of health care providers they consulted for health problems, history of jaundice, history of taking injections, previous surgical procedures, frequency of dental visits, receiving blood or blood products, history of current/past use of intravenous drugs, and visiting community barbers for shaving in males. and serological testes for HBs Ag and HCV antibodies had been performed by rapid acting test [14].

\section{Statistical analysis}

Data were entered checked and analyzed using Epi-Info version 6 and SPP for Windows version 8 [15] $\mathrm{X}^{2}$ (chi-squared) used for difference between two or more qualitative variable. Correlation between variables was done using correlation coefficient " $r$ ". in all tests $(p<0.05)$ is significant and $(p<0.001)$ is highly significant. 


\section{RESULTS}

Table (1) showed prevalence of HCV Abs and HBs Ag among workers of Zagazig Faculty of Medicine Departments and its Hospitals. Hepatitis $\mathrm{C}$ virus (HCV) antibodies was detected in $39(19.5 \%)$ and Hepatitis B surface antigen 7 (3.5\%) and both HBsAg and anti-HBc were positive in $1((0.5 \%)$.

Table (2) showed prevalence of HCV Abs and HBs Ag among workers of Zagazig Faculty of Medicine Departments and its Hospitals in relation to Sex. HCV and HBV prevalence was higher among males 30/148 (20.27) \% and $6 / 148(4 \%)$ compared to females $9 / 52(17.3 \%)$ and $1 / 52(1.92 \%$ respectively) and the Prevalence of both $\mathrm{HBs} \mathrm{Ag}$ and $\mathrm{HCV}$ Abs was 1/148 $(0.7) \%$ in males and negative in females .

Table (3) showed correlation between Prevalence of HCV Abs among workers of Zagazig Faculty of Medicine Departments and its Hospitals and risk factors of transmission, $46.15 \%$ of $\mathrm{HCV}$ seropositivity was reported in workers with past history of dental procedure (OR 1.44), 23.08\% had history of operation (OR 1.2) 7.69\% had history of blood transfusion ( OR 1.59 ) but
$69.23 \%$ had past history of barbering (OR 4.58 ) which gives four times risk of $\mathrm{HCV}$ infection .

Table (4) showed correlation between Prevalence of HCV Abs among workers of Zagazig Faculty of Medicine Departments and its Hospitals and occupational exposure. The highest risk was reported with workers in operation units and surgical departments OR $>3.36$.

Table (5) showed correlation between prevalence of HBs Ags among workers of Zagazig Faculty of Medicine Departments and its Hospitals and risk factors of transmission. The highest risk was recorded in workers with past history of blood transfusion (OR 8.18) compared with history of dental procedure,(OR0.29), barbering(OR0.59) and operation (OR1.58).Blood transfusion gives eight times risk of $\mathrm{HBV}$ infection.

Table (6) showed correlation between Prevalence of HBs Ags among workers of Zagazig Faculty of Medicine Departments and its Hospitals and occupational exposure. The highest risk was reported with workers in operation units OR 4.42 and to less extent in surgical units OR1.17.

Table (1): Prevalence of HCV Abs and HBs Ag among workers of Zagazig Faculty of Medicine Departments and its Hospitals

\begin{tabular}{|c|c|c|c|}
\hline & & $\begin{array}{c}\text { Number }(200 \\
\text { workers })\end{array}$ & $\begin{array}{c}\text { Percentage } \\
\%\end{array}$ \\
\hline \multirow{2}{*}{ HCV Abs } & positive & 39 & $19.5 \%$ \\
\cline { 2 - 4 } & negative & 161 & $80.5 \%$ \\
\hline \multirow{2}{*}{ HBs Ag } & positive & 7 & $3.5 \%$ \\
\cline { 2 - 4 } & negative & 193 & $96.5 \%$ \\
\hline \multirow{2}{*}{ Both HBs Ags \& HCV Abs +ve workers } & 1 & $0.5 \%$ \\
\hline
\end{tabular}

Table (2): Prevalence of HCV Abs and HBs Age in relation to sex

\begin{tabular}{|l|c|c|c|c|}
\hline & $\begin{array}{c}\text { Male } \\
(\mathbf{1 4 8})\end{array}$ & $\begin{array}{c}\text { Female } \\
(\mathbf{5 2})\end{array}$ & $\mathbf{X}^{\mathbf{2}}$ & $\mathbf{P}$ \\
\hline HBs Ags (+ve ) workers & $\begin{array}{c}6 \\
(4 \%)\end{array}$ & $\begin{array}{c}1 \\
(1.92 \%)\end{array}$ & Fisher & 0.67 \\
\hline HCV Abs (+ve) workers & $\begin{array}{c}30 \\
(20.27 \%)\end{array}$ & $\begin{array}{c}9 \\
(17.3 \%)\end{array}$ & 0.22 & 0.64 \\
\hline Both HBs Ags \& HCV Abs +ve workers & $\begin{array}{c}1 \\
(0.7 \%)\end{array}$ & & Fisher & 1.0 \\
\hline
\end{tabular}


Table (3): Correlation between Prevalence of HCV Abs and risk factors of transmission (dental procedure, Barbering, operation, and blood transfusion).

\begin{tabular}{|c|c|c|c|c|c|c|}
\hline & \multicolumn{2}{|c|}{$\mathrm{HCV} \mathrm{ab}$} & \multirow[t]{2}{*}{ O.R } & \multirow[t]{2}{*}{$X^{2}$} & \multirow[t]{2}{*}{$\mathrm{p}$} \\
\hline & & positive & negative & & & \\
\hline \multirow{2}{*}{$\begin{array}{l}\text { Dental } \\
\text { history }\end{array}$} & Yes & $\begin{array}{c}18 \\
(46.15 \%) \\
\end{array}$ & $\begin{array}{c}60 \\
(59.41 \%) \\
\end{array}$ & \multirow[t]{2}{*}{$\begin{array}{c}1.44 \\
(0.67-3.09)\end{array}$} & \multirow[t]{2}{*}{1.04} & \multirow[t]{2}{*}{0.31} \\
\hline & No & $\begin{array}{c}21 \\
(53.85 \%)\end{array}$ & $\begin{array}{c}161 \\
(40.59 \%)\end{array}$ & & & \\
\hline \multirow{2}{*}{$\begin{array}{l}\text { History of } \\
\text { barbering }\end{array}$} & Yes & $\begin{array}{c}27 \\
(69.23 \%)\end{array}$ & $\begin{array}{c}53 \\
(33.125 \%)\end{array}$ & \multirow[t]{2}{*}{$\begin{array}{c}4.58 \\
(2.03-10.48)\end{array}$} & \multirow[t]{2}{*}{17.25} & \multirow[t]{2}{*}{$0.000^{*}$} \\
\hline & No & $\begin{array}{c}12 \\
(30.77 \%) \\
\end{array}$ & $\begin{array}{c}108 \\
(66.875 \%) \\
\end{array}$ & & & \\
\hline \multirow{2}{*}{$\begin{array}{l}\text { History of } \\
\text { operation }\end{array}$} & Yes & $\begin{array}{c}9 \\
(23.08 \%) \\
\end{array}$ & $\begin{array}{c}32 \\
(19.88 \%) \\
\end{array}$ & \multirow[t]{2}{*}{$\begin{array}{c}1.21 \\
(0.48-2.99)\end{array}$} & \multirow[t]{2}{*}{0.20} & \multirow[t]{2}{*}{0.65} \\
\hline & No & $\begin{array}{c}30 \\
(86.92 \%) \\
\end{array}$ & $\begin{array}{c}129 \\
(80.12) \\
\end{array}$ & & & \\
\hline \multirow{2}{*}{$\begin{array}{l}\text { History of blood } \\
\text { Transfusion }\end{array}$} & Yes & $\begin{array}{c}3 \\
(7.69 \%) \\
\end{array}$ & $\begin{array}{c}8 \\
(4.97 \%) \\
\end{array}$ & \multirow[t]{2}{*}{$\begin{array}{c}1.59 \\
(0.32-7.08)\end{array}$} & \multirow[t]{2}{*}{$\begin{array}{l}\text { Fisher } \\
\text { Exact }\end{array}$} & \multirow[t]{2}{*}{0.45} \\
\hline & No & $\begin{array}{c}36 \\
(92.31 \%) \\
\end{array}$ & $\begin{array}{c}153 \\
(95.03 \%) \\
\end{array}$ & & & \\
\hline
\end{tabular}

Table (4): Correlation between Prevalence of HCV Abs and occupational exposure

\begin{tabular}{|c|c|c|c|c|c|c|c|}
\hline \multirow{2}{*}{\multicolumn{2}{|c|}{ Department }} & \multicolumn{2}{|c|}{ HCV Abs } & \multirow{2}{*}{ Total } & \multirow{2}{*}{ OR } & \multirow{2}{*}{$\mathbf{X}^{2}$} & \multirow[t]{2}{*}{$\mathbf{P}$} \\
\hline & & $\begin{array}{c}\text { Positive } \\
7\end{array}$ & $\begin{array}{c}\text { Negative } \\
193\end{array}$ & & & & \\
\hline \multicolumn{2}{|c|}{ Administration } & $\begin{array}{c}8 \\
(10.8 \%) \\
\end{array}$ & $\begin{array}{c}66 \\
(89.2 \%) \\
\end{array}$ & $\begin{array}{c}74 \\
(100 \%) \\
\end{array}$ & $0.37(0.15-0.91)$ & 5.65 & $0.01 *$ \\
\hline \multicolumn{2}{|c|}{ Operation units } & $\begin{array}{c}12 \\
(37.5 \%)\end{array}$ & $\begin{array}{c}20 \\
(62.5 \%)\end{array}$ & $\begin{array}{c}32 \\
(100 \%)\end{array}$ & $3.13(1.27-7.71)$ & 7.86 & $0.005 *$ \\
\hline \multicolumn{2}{|c|}{ ICU } & $\begin{array}{c}3 \\
(20 \%) \\
\end{array}$ & $\begin{array}{c}12 \\
(80 \%) \\
\end{array}$ & $\begin{array}{c}15 \\
(100 \%) \\
\end{array}$ & $1.03(0.22-4.24)$ & FISHER & 1.0 \\
\hline \multirow[t]{2}{*}{ Departments } & Surgical & $\begin{array}{c}10 \\
(40 \%) \\
\end{array}$ & $\begin{array}{c}15 \\
(60 \%) \\
\end{array}$ & $\begin{array}{c}25 \\
(100 \%) \\
\end{array}$ & $3.36(1.25-8.93)$ & FISHER & $0.01 *$ \\
\hline & $\begin{array}{c}\text { Non } \\
\text { surgical }\end{array}$ & $\begin{array}{c}4 \\
(8.7 \%) \\
\end{array}$ & $\begin{array}{c}42 \\
(91.3 \%) \\
\end{array}$ & $\begin{array}{c}46 \\
(100 \%) \\
\end{array}$ & $0.32(0.09-0.99)$ & 4.44 & $0.03 *$ \\
\hline \multicolumn{2}{|c|}{ Out Patients } & $\begin{array}{c}2 \\
(25 \%)\end{array}$ & $\begin{array}{c}6 \\
(75 \%)\end{array}$ & $\begin{array}{c}8 \\
(100 \%)\end{array}$ & $1.4(0.19-8.12)$ & FISHER & 0.65 \\
\hline
\end{tabular}


Table (5): Correlation between Prevalence of HBs Ags and and risk factors of transmission (dental procedure, Barbering, operations, blood transfusion).

\begin{tabular}{|c|c|c|c|c|c|c|}
\hline & \multicolumn{2}{|c|}{ HBs Ag } & \multirow{2}{*}{ O.R } & \multirow[t]{2}{*}{$\mathrm{X}^{2}$} & \multirow{2}{*}{$\mathrm{p}$} \\
\hline & & positive & negative & & & \\
\hline \multirow{2}{*}{$\begin{array}{l}\text { Dental } \\
\text { History }\end{array}$} & Yes & $\begin{array}{c}2 \\
(28.57 \%\end{array}$ & $\begin{array}{c}106 \\
(54.92\end{array}$ & \multirow{2}{*}{$\begin{array}{c}0.29 \\
(0.04-1.75)\end{array}$} & \multirow{2}{*}{$\begin{array}{l}\text { Fisher } \\
\text { exact }\end{array}$} & \multirow{2}{*}{0.24} \\
\hline & No & $\begin{array}{c}5 \\
(71.43 \%)\end{array}$ & $\begin{array}{c}87 \\
(45.08 \%)\end{array}$ & & & \\
\hline \multirow{2}{*}{$\begin{array}{l}\text { History of } \\
\text { Barbering }\end{array}$} & Yes & $\begin{array}{c}2 \\
28.57 \%)\end{array}$ & $\begin{array}{c}78 \\
(40.41 \%)\end{array}$ & \multirow{2}{*}{$\begin{array}{c}0.59 \\
(0.08-3.54)\end{array}$} & \multirow{2}{*}{$\begin{array}{l}\text { Fisher } \\
\text { exact }\end{array}$} & \multirow{2}{*}{0.70} \\
\hline & No & $\begin{array}{c}5 \\
(71.43 \%) \\
\end{array}$ & $\begin{array}{c}115 \\
(59.59 \%) \\
\end{array}$ & & & \\
\hline \multirow{2}{*}{$\begin{array}{l}\text { History of } \\
\text { operation }\end{array}$} & Yes & $\begin{array}{c}2 \\
(28.57 \%)\end{array}$ & $\begin{array}{c}39 \\
(20.20 \%)\end{array}$ & \multirow{2}{*}{$\begin{array}{c}1.58 \\
(0.2-9.70)\end{array}$} & \multirow{2}{*}{$\begin{array}{l}\text { Fisher } \\
\text { exact }\end{array}$} & \multirow{2}{*}{0.63} \\
\hline & No & $\begin{array}{c}5 \\
(71.43 \%\end{array}$ & $\begin{array}{c}154 \\
(79.80 \%)\end{array}$ & & & \\
\hline \multirow{2}{*}{$\begin{array}{l}\text { History of } \\
\text { blood } \\
\text { Transfusion }\end{array}$} & Yes & $\begin{array}{c}2 \\
(28.57 \% \\
\end{array}$ & $\begin{array}{c}9 \\
(4.66 \%)\end{array}$ & \multirow{2}{*}{$\begin{array}{c}8.18 \\
(1.0-59.5)\end{array}$} & \multirow{2}{*}{$\begin{array}{l}\text { Fisher } \\
\text { exact }\end{array}$} & \multirow{2}{*}{$0.04 *$} \\
\hline & $\mathrm{NO}$ & $\begin{array}{c}5 \\
(71.43 \%)\end{array}$ & $\begin{array}{c}184 \\
(95.34 \%)\end{array}$ & & & \\
\hline
\end{tabular}

Table (6): Correlation between Prevalence of HBs Ags and occupational exposure

\begin{tabular}{|c|c|c|c|c|c|c|c|}
\hline \multirow{2}{*}{\multicolumn{2}{|c|}{ Department }} & \multicolumn{2}{|c|}{ HBs Ag } & \multirow[t]{2}{*}{ Total } & \multirow[t]{2}{*}{$\overline{\text { OR }}$} & \multirow[t]{2}{*}{$\overline{X^{2}}$} & \multirow[t]{2}{*}{$\mathbf{P}$} \\
\hline & & $\begin{array}{c}\text { Positive } \\
7\end{array}$ & $\begin{array}{c}\text { Negative } \\
193\end{array}$ & & & & \\
\hline \multicolumn{2}{|c|}{ Administration } & $\begin{array}{c}2 \\
(2.7 \%)\end{array}$ & $\begin{array}{c}72 \\
(97.3 \%)\end{array}$ & $\begin{array}{c}74 \\
(100 \%)\end{array}$ & $0.67(0.09-4.05)$ & FISHER & 1.0 \\
\hline \multicolumn{2}{|c|}{ Operation units } & $\begin{array}{c}3 \\
(9.4 \%)\end{array}$ & $\begin{array}{c}29 \\
(90.6 \%)\end{array}$ & $\begin{array}{c}32 \\
(100 \%)\end{array}$ & $4.24(0.71-24.1)$ & FISHER & 0.08 \\
\hline \multicolumn{2}{|l|}{ ICU } & $\begin{array}{c}0 \\
(0.0 \%)\end{array}$ & $\begin{array}{c}15 \\
(100 \%)\end{array}$ & $\begin{array}{c}15 \\
(100 \%)\end{array}$ & $0.0(0.0-10.4)$ & FISHER & 1.0 \\
\hline \multirow[t]{2}{*}{ Departments } & Surgical & $\begin{array}{c}1 \\
(4 \%)\end{array}$ & $\begin{array}{c}24 \\
(96 \%)\end{array}$ & $\begin{array}{c}25 \\
(100 \%)\end{array}$ & $1.17(0.5-9.3)$ & FISHER & 1.0 \\
\hline & \begin{tabular}{|l|} 
Non \\
surgical
\end{tabular} & $\begin{array}{c}0 \\
(0.0 \%)\end{array}$ & $\begin{array}{c}46 \\
(100 \%)\end{array}$ & $\begin{array}{c}46 \\
(100 \%)\end{array}$ & $0.0(0.0-2.6)$ & FISHER & 0.35 \\
\hline
\end{tabular}

\section{DISCUSSION}

In comparison to rate of $\mathrm{HBsAg}$ and $\mathrm{HCV}$ infection, in general population of Egypt, The current study presented the prevalence of $\mathrm{HBV}$ surface antigens and $\mathrm{HCV}$ antibodies among workers of Zagazig Faculty of Medicine and its Hospitals. In our study, HCV Abs was detected in 19.5 percent of the workers of Zagazig Faculty of medicine and its hospitals. Our findings were consistent with El-Zanaty [5] who mentioned that the prevalence is as high as $20 \%$ in Egypt. In our study, the prevalence of HCV Abs in males is 20.27 percent and in females is 17.3 percent. Males had considerably higher rates of $\mathrm{HCV}$ antibodies than females. Similar results were reported in a cross-sectional survey in Upper
Egypt, in which the prevalence of HCV Abs was higher among males than females $(12 \%$ and $8 \%$, respectively and it was also highest among those $>30$ years of age [16].The most likely explanation for the higher prevalence among males than females is that males make more frequent visits to barber shops than females and may share shaving equipment, and circumcision for boys by informal health care providers was marginally associated with $\mathrm{HCV}$ infection [17]. In our study, the prevalence of $\mathrm{HCV}$ Abs is 27 (69.32) of $39 \mathrm{HCV}$ seropositive patients with past history of barbering, Razor sharing and shaving in barber shops has been identified as a key risk factor of transmission of HCV.Many workers consider infection with $\mathrm{HCV}$ to be an 
occupational hazard for barbers [26] Other researchers consider barbers a source of infection to their clients, especially when there is reuse of razor blades that may transmit infection through micro-trauma [26] ,howeve, others found no relation between shaving by community barbers and infection with viral hepatitis [17]. The current study reported that $18(46.15 \%)$ of 39 HCV-seropositive patients with a past history of dental procedure with an O.R. 1.44 (0.67-3.09). An analysis of data on acute viral hepatitis collected by an Italian surveillance system found that 9 percent of all cases of acute HCV infection had only a history of dental work as a risk factor [18].

In our study, the prevalence of HCV Abs is 9 $(23.08 \%)$ of $39 \mathrm{HCV}$-seropositive patients with a past history of operation with an O.R. 1.21 (0.48-2.99). There is no significant association between seropositivity of $\mathrm{HCV}$ and past history of operation. The risk of acquiring hepatitis $\mathrm{C}$ by needle-stick injury is extremely low, ranging from 0 to $10.3 \%$ [19].

In our study, the prevalence of HCV Abs 3 (7.69\%) of 39 of workers with a past history of blood transfusion O.R.1.59 (0.32-7.08). There is no significant association between seropositivity of $\mathrm{HCV}$ and past history of blood transfusion the result is an agreement with Khattab [20] who found that $13.6 \%$ of Egyptian blood donors were serologically confirmed to be infected with $\mathrm{HCV}$. Infection with $\mathrm{HCV}$ is reduced due to effective blood screening before blood transfusion [12]. Incidence of transfusion related hepatitis $\mathrm{C}$ is still higher in some areas of the world. In a study of 147 Chilean patients with chronic hepatitis $\mathrm{C}$, the most common risk factor was blood transfusion in 54\% [21]. In our study, the prevalence of $\mathrm{HCV}$ Abs is $3(10.2 \%)$ of 15 workers of ICU with an O.R1.03(0.22-4.24) and the prevalence of HCV Abs is $2(25 \%)$ of 8 workers of out patients with an O.R 1.4(0.198.12) and the seropositvity of HCV due to frequent contact with infected people. There is no significant association between seropositivity of HCV and working in these Departments. This is due to good infection control program. Neal [22] reported that healthcare workers are at greater risk of exposure to the hepatitis $\mathrm{C}$ virus than the rest of the general population.

HBV infection is one of the most important infectious diseases worldwide. Around one million persons die of $\mathrm{HBV}$-related causes annually. Egypt is considered as intermediate prevalence area (3-11\%) (20). In our study, HBs $\mathrm{Ag}$ was detected in 3.5 percent of the workers of Zagazig Faculty of medicine and its hospitals. Our findings were consistent with the prevalence (3-5\%) in the Mediterranean countries, Japan, Central Asia, the Middle East, and Latin and South America [11].

In our study, the prevalence of HBs $\mathrm{Ag} \mathrm{Abs}$ in males is 4 percent and in females is 1.92 percent. Males had considerably higher rates of HBs Ags than females. Similar figures were reported from a study in Pakistan in which the prevalence was $2.5 \%$ for $\mathrm{HBs} \mathrm{Ag}$, and among them the majority of cases were males [23].

In our study, the prevalence of $\mathrm{HBs} \mathrm{Ag}$ is 2 $(28.57 \%)$ of 7 workers with a past history of dental procedure with an O.R. 0.29 (0.04-1.75). There is no significant association between seropositivity of HBV infection and history of dental procedure. Vectors of infection with HBV in dental practice are blood, saliva and nasopharyngeal secretions [24]. In our study, the prevalence of $\mathrm{HBs} \mathrm{Ag}$ is $2(28.57 \%)$ of 7 of workers with history of barbering with an O.R. $0.59(0.08-3.54)$. There is no significant association between sero positivity of HBV infection and history of barbering. Facial shaving from barbers has been repeatedly documented as a risk factor for transmission of $\mathrm{HBV}$ in various countries and is well known to cause abrasions and small cuts [25]

In our study, the prevalence of $\mathrm{HBs} \mathrm{Ag}$ is $2(28.57 \%)$ of 7 of workers with history of operation with an O.R. $1.58(0.2-9.70)$. There is no significant association between seropositivity of HBV infection and history of operation, Due to the implementation of routine vaccination of health care workers the incidence of $\mathrm{HBV}$ infection among them is lower than in the general population. Therefore, transmission from healthcare workers to patients is a rare event, while the risk of transmission from an HBVpositive patient to a healthcare worker seems to be higher [26]. In our study, the prevalence of HBs Ag is 2 (28.57 of 72 of workers of Administration with an O.R. $0.67(0.09-4.05)$ .The prevalence of HBs Ag is 1 (28.57\%) of 7 of workers of Out Patients with an O.R. 4.0(0.529.1). The prevalence of HBs Ag is 1 (28.57 \%) of 24 of workers of surgical departments with an O.R. 1.17 (0.5-9.3). There is no significant association between seropositivity of $\mathrm{HBs} \mathrm{Ag}$ 
infection and occupational exposure, although the risk of transmission increased 4 fold in operation units and out patient due to exposure to blood, blood products and surgical instruments. Exposure to blood and body fluids remains an important concern for healthcare workers, especially those who sustain a percutaneous injury. The risk of acquiring hepatitis B infection following a needle stick injury is estimated at approximately $30 \%[27]$.

We conclude that the prevelance of HCV Abs among workers was $19.5 \%$ with males affection more than females .In HCV Abs positive workers $46.15 \%$ had history of dental procedure, $69.27 \%$ had history of barbering, $23.08 \%$ had history of operation, $7.6 \%$ had history of blood transfusion, Barbering increase the risk of HCV transmission 4 times.Workers of surgical departments showed $40 \%$ for positivity of HCV Abs and in operation units $37.5 \%$, both increase the risk of transmission more than 3 times, Also workers in non surgical department and administration showed significant association with $\mathrm{HCV}$ Abs positivity. The prevelance of $\mathrm{HBV} \mathrm{Ag}$ among workers was $3.5 \%$ with males affection more than females, HBVAg positivity was significantly associated with history of blood transfusion $(\mathrm{p}<0.05)$, with 8 fold increase the risk of transmission, the prevelance of HBS Ag was $9.4 \%$ among workers in operation units, with increase risk of transmission 4.24 times. All of the above reflect the importance of infectious control measures not only in ICU, but also in all departments, including operation surgical and non surgical and even administration. Increase puplic awareness of these infections, modes of transmission, ways of prevention may help to reduce the prevelance of both $\mathrm{HCV}$ and $\mathrm{HBV}$.

Funding: No funding resourses .

Conflicts of interest: The authors report no conflicts of interest. The authors alone are responsible for the content and writing of the paper.

\section{Ethical approval: Approved.}

\section{REFERENCES}

1. WHO: WHO Int. World Health Organization fact sheet, hepatitis C. Available via: Fact sheet $\mathrm{N}^{\circ} 204$ July 2012.

2. Sievert W, Altraif I, Razavi H, . A systematic review of hepatitis $\mathrm{C}$ virus epidemiology in Asia, Australia and Egypt. Liver Int ,2011; 31 (Suppl 2):61-80.
3. Strickland G. Liver disease in Egypt: hepatitis C superseded schistosomiasis as a result of iatrogenic and biological factors .Hepatology, 2006; 43:915-22.

4. Talaat M, Kandeel A, Rasslan O . Evolution of infection control in Egypt: achievements and challenges. Am J Infect Control 2006 ; 34:193200.

5. El Zanaty F, Way A . Knowledge and prevalence of hepatitis C.EDHS 2009: 251-258.

6. Paez Jimenez A, Sharaf Eldin N, Rimlinger F. $\mathrm{HCV}$ iatrogenic and intrafamilial transmission in greater Cairo,Egypt. Gut 2010 ; 59:1554-60.

7. Mostafa A, Taylor S, El-Daly M. . Is the hepatitis $\mathrm{C}$ virus epidemic over in Egypt? Incidence and risk factors of new hepatitis $\mathrm{C}$ virus infections. Liver Int $2010 ; 31: 560-6$.

8. Nelson, PK; Mathers BM, Cowie B."Global epidemiology of hepatitis B and hepatitis C in people who inject drugs: results of systematic reviews" .Lancet 2011 ;378 (9791): 571-83.

9. Gomaa AI, Khan SA, Toledano MB. Hepatocellular carcinoma: epidemiology, risk factors and pathogenesis.World $J$ Gastroenterology 2008; 14(27): 4300.

10. Wasley A, Grytdal S and Gallagher K. Surveillance for acute viral hepatitis: United States. MMWR Surveill Summ 2008; 57(2):1.

11. Gilca V, De Serres G, Boulianne N..Antibody kinetics among 8-10 years old respondents to hepatitis B vaccination in a low endemic country and the effect of a booster dose given five or ten years later. Vaccine $2009 ; 27(43): 6048-53$.

12. Busch MP, Glynn SA, Stramer SL, Strong DM. A new strategy for estimating risks of transfusion-transmitted viral infections based on rates of detection of recently infected donors.Transfusion 2005;45: 254-264

13. Nico Lelie, Evangelia Walker, Charl Coleman, Mark Keyter; Hepatitis B virus transmission by blood transfusion during 4 years of individualdonation nucleic acid testing in South Africa: estimated and observed window period risk. Transfusion 2012; 52: 880-892.

14. Hoofnagle JH, di Bisceglie AM. Serologic diagnosis of acute and chronic viral hepatitis. Semin Liver Dis 1991.;11:73-83

15. Dean A., Dean J. and Brendele K.Epi-Info version 6.02 ward processing data base and statistics program for epidemiology Microcomputer CDC, Atlanta, Gerogia USA 2006. 620.

16. Darwish MA, .: Prevalence of HCV and HBV antibodies among intravenous drug adults and associated risk factors. Egyptian Journal of Medical Laboratory Sciences 2005; 14.

17. El -Raziky MS.: Prevalence and risk factors of asymptomatic hepatitis $\mathrm{C}$ virus infection in Egyptian children. World Journal of Gastroenterology 2007; 13:1828-1832. 
18. Mele, Tosti, Marzolini, Moiraghi. :Prevention of hepatitis $\mathrm{C}$ in Italy: lessons from surveillance of type-specific acute viral hepatitis.J. of Viral Hepatitis 2000; V 7, P 30-35.

19. Lowenfals A, Mehta V, Levi D.. Reduced frequency of percutaneous injuries in surgeons: 1993 versus 1988. AIDS 1995; 9:199-202.

20. Khattab MA, Eslam M, Sharwae MA, HamdyL(2010). Seroprevalence of hepatitis C and B among blood donors in Egypt: Minya Governorate, 2000-2008. Am J Infect Control. 2010; 38(8):640-1.

21. Soza A, Arrese M Gonzalez R, Alvarez M. Clinical and epidemiological features of 147 Chilean patients with chronic C. Ann Hepatology 2004 ; 3 (4):146-51.

22. Neal KR, Dornan J, Irving WL. Prevalence of hepatitis $\mathrm{C}$ antibodies among healthcare workers of two teaching hospitals. Who is at risk? BMJ 2004 7;314:179-80.

23. Amin J, Yousuf H, Mumtaz A, Iqbal M, Ahmed R, Adhami SZ, et al.,. Prevalence of hepatitis B surface antigen and anti hepatitis $\mathrm{C}$ virus among general population in Lahore. Prof Med J 2004; 11:334-7

24. Kidd-Ljunggren $\mathrm{K}$, Holmberg A, Bläckberg J, Lindqvist B. "High levels of hepatitis B virus
DNA in body fluids from chronic carriers". The Journal of Hospital Infection 2006 (4): 52-7.

25. Jokhio AH, Bhatti TA, and Memon S. Knowledge, attitudes and practices of barbers about hepatitis $\mathrm{B}$ and $\mathrm{C}$ transmission in Hyderabad. Pakistan East Mediterr Health J, 2010;16(10):1079-84.

26. Duseja A, Arora L, Masih B. Hepatitis B and C virus: Prevalence and prevention in health care workers. Trop Gastroenterology2002;23(3):125.

27. Hanafi MI, Mohamed AM, Kassem MS, Shawki M. Needle stick injuries among health care workers of University of Alexandria Hospitals. Eastern Mediterranean Health Journal. 2011 ;17(1):26-35.]

Peer Reviewer: Salem Eldeeb; Professor of Nephrology and Internal Medicine, Zagazig Faculty of Medicine, Egypt.

Editor: Tarik Zaher ;Assistant Professor of Tropical Medicine, Zagazig Faculty of Medicine, Egypt. 